\title{
Application of Gene Expression Programming for Performance Analysis of a Regenerative Organic Rankine Cycle with Low-Temperature Heat Source
}

\author{
Arzu Şencan Şahin*, Erkan Dikmen \\ Mechanical Engineering Department, Technology Faculty, Isparta University of Applied Sciences, Isparta, Turkey.
}

\begin{abstract}
How to cite this paper: Arzu Şencan Şahin, Erkan Dikmen. (2022) Application of Gene Expression Programming for Performance Analysis of a Regenerative Organic Rankine Cycle with Low-Temperature Heat Source. Journal of Electrical Power \& Energy Systems, 6(1), 24-33.

DOI: $10.26855 /$ jepes.2022.01.003
\end{abstract}

Received: November 11, 2021

Accepted: December 15, 2021

Published: January 25, 2022

*Corresponding author: Arzu Şencan Şahin, Mechanical Engineering Department, Technology Faculty, Isparta University of Applied Sciences, Isparta, Turkey.

Email: arzusencan@isparta.edu.tr

\begin{abstract}
In this study, the performance analysis of the Regenerative Organic Rankine Cycle (RORC) by using the Gene Expression Programming (GEP) was carried out. Working fluids R-123 and R-134a have been used in the RORC. GEP model was developed to predict thermodynamic performances of the RORC depending on the steam generator, condenser, subcooling, and superheating temperature. To investigate the accuracy of the model, root mean square error (RMSE), mean absolute percentage error (MAPE), and coefficient of determination $\left(\mathrm{R}^{2}\right)$ was employed. For R123, the optimal values of RMSE, MAPE, and $\mathrm{R}^{2}$ are 0.00004228, 0.01377, and 0.9532, respectively. For R-134a, the optimal values of RMSE, MAPE, and $\mathrm{R}^{2}$ are 0.00002413 , 0.01226 , and 0.9613 , respectively. The results showed that the GEP model results and actual values are in fairly well agreement. The formulas obtained from the GEP model are relatively short, simple and reliable. So, these formulas will assist engineers to very accurately and quickly estimate the thermal efficiency of the regenerative organic Rankine cycle.
\end{abstract}

\section{Keywords}

Organic Rankine Cycle, performance analysis, Gene expression programming, regenerative

\section{Introduction}

The working principle of the Organic Rankine Cycle (ORC) is parallel to the traditional Rankine cycle. The basic distinction is the use of organic items instead of water or steam as working fluid. ORC is a well-known and widely spread form of energy production. The most important advantage of the ORC according to the traditional Rankine cycle is suitable for lower temperature applications. Thus, biomass, geothermal, solar energy, and low-grade waste heat for ORC can be used. Different researchers have studied for optimization and thermodynamic analysis of ORC systems. Roy et al. [1] performed the optimization and analysis of the regenerative ORC. As working fluids; R-12, R-123, R-134a, and R-717 were used. Working fluid R-123 provides maximum system efficiency. Kumar et al. [2] 
carried out the optimization of the ORC. Analyzes were performed using Taguchi's method. The analysis also shows that the turbine temperature has large effects on efficiency. Huang et al. [3] performed thermodynamic analysis and optimization of novel ORC. Feidt et al. [4] investigated the thermodynamic performance of an ORC using low global warming potential working fluids. Li et al. [5] carried out thermodynamic performance analyses and optimization of subcritical and transcritical organic Rankine cycles using R1234ze (E). Zhu et al. [6] performed parametric optimization and performance analysis of an ORC for waste heat recovery from the marine diesel engine. Yuksel [7] performed energy and exergy analysis of integrated geothermal plant with proton exchange membrane electrolyzer, hydrogen compression unit, organic Rankine cycles, single effect absorption cooling cycle, hot water storage tank and a drying unit. Akbay and Yilmaz [8] carried out energy and exergy analysis of a geothermal power generation system with a direct steam turbine and organic Rankine cycle.

Recently, different optimization techniques (artificial neural network, genetic algorithm, genetic programming, gene expression programming, etc.) have been successfully applied to various engineering areas. The gene expression programming (GEP) model does not time-consuming and unneeded high numbers of iterations. Therefore, researchers have increasingly preferred this model. In literature, the gene expression programming (GEP) model has been successfully used in a lot of engineering applications. Şencan et al. [9] used the GEP model for estimating thermodynamic properties of R513a refrigerant. The obtained results showed that this model can be used to predict the thermodynamic properties of the refrigerant. Leon and Gayexplores [10] explored the use of GEP to predict permanent deformation of asphalt concrete with the inclusion of aggregate angularity. Compared with regression analysis, the permanent deformation estimation results obtained by the GEP method are satisfactory. Mattar [11] used GEP model for estimating monthly reference evapotranspiration in Egypt. Wind speed and relative humidity have a great impact in calculating evapotranspiration. The results showed that the GEP model is can be employed successfully in modeling evapotranspiration. Kaboli et al. [12] used GEP model for long-term electrical energy consumption formulating and forecasting. The results show that the higher accuracy of the GEP model as compared with other artificial intelligence based models. Dikmen et al. [13] used GEP model to determine drying behavior of herbal plants. The results have shown that the GEP model can be considered as an efficient modeling technique for the prediction of moisture ratio of herbal plants. Şahin et al. [14] estimated with GEP approach thermodynamic properties of working fluids used on Organic Rankine Cycle. The obtained results showed that the formulations are effectively capable of evaluating the thermodynamic properties of working fluids.

As seen from literature research, performance analysis and optimization of organic Rankine systems have been carried out by a lot of researchers. Nevertheless, there are no studies on the performance analysis of RORC systems using the GEP model in the literature. In work, the GEP model to predict the thermal efficiency of the RORC using working fluids R-123 and R-134a was used. The thermophysical and environmental properties of working fluids are shown in Table 1 [1].

Table 1. The thermophysical and environmental properties of working fluids [1]

\begin{tabular}{ccc}
\hline Property & R-123 & R-134a \\
\hline Molecule weight $(\mathrm{g} / \mathrm{mol})$ & 152.93 & 102.03 \\
Boiling temperature $\left({ }^{\circ} \mathrm{C}\right)$ & 27.85 & -26.15 \\
Critical temperature $\left({ }^{\circ} \mathrm{C}\right)$ & 183.79 & 101.06 \\
Critical pressure (bar) & 36.74 & 40.56 \\
Ozone depletion potential (ODP) & 0.012 & 0 \\
Global warming potential (GWP) & 120 & 1300 \\
\hline
\end{tabular}




\section{Regenerative Organic Rankine Cycle}

The Regenerative Organic Rankine Cycle (RORC) is like the traditional Rankine cycle. As shown in Figure 1, the RORC consists of a steam generator, a turbine, a condenser, a regenerator, and a pump. The thermal efficiency of the RORC can be found depending on different operating parameters.

Following assumptions are given for performance analysis of the RORC:

- The pressure loss in system components and piping are neglected.

- System components are considered under steady-state steady-flow conditions.

The thermodynamic equations for the RORC seen in Fig.1 are described as follows.

Pump: The pump power is given by:

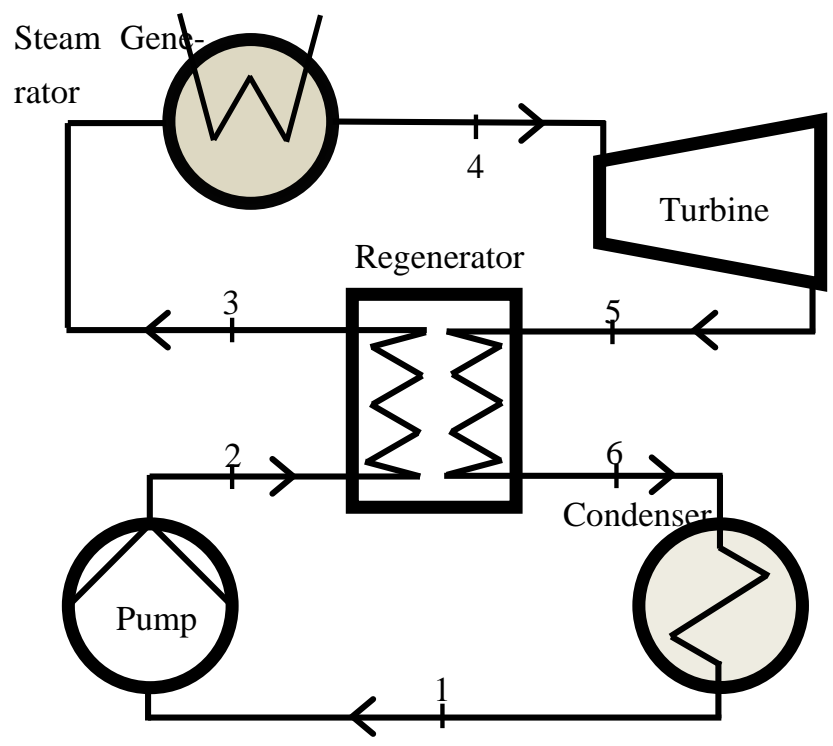

Figure 1. Configuration of a regenerative Organic Rankine Cycle.

$$
\dot{W}_{P}=\dot{m}\left(h_{2}-h_{1}\right)
$$

Steam Generator: The heat transfer rate for the steam generator is given by:

$$
\dot{Q}_{G}=\dot{m}\left(h_{4}-h_{3}\right)
$$

Turbine: The turbine power is given by:

$$
\dot{W}_{T}=\dot{m}\left(h_{4}-h_{5}\right)
$$

Condenser: The heat transfer rate in the condenser is given by:

$$
\dot{Q}_{C}=\dot{m}\left(h_{6}-h_{1}\right)
$$

The thermal efficiency of the RORC system can be expressed as:

$$
\eta=\frac{\dot{W}_{T}-\dot{W}_{P}}{\dot{Q}_{G}}=\frac{\left(h_{4}-h_{5}\right)-\left(h_{2}-h_{1}\right)}{\left(h_{4}-h_{3}\right)}
$$

Figure 2 and Figure 3 show the variation of thermal efficiency with evaporator and condenser temperatures for R-123 and R-134a fluids, respectively. As seen in Figure 2 and Figure 3, the thermal efficiency increased with the increase of the evaporator temperature. The thermal efficiency of the system decreases when increasing the condenser temperature. 


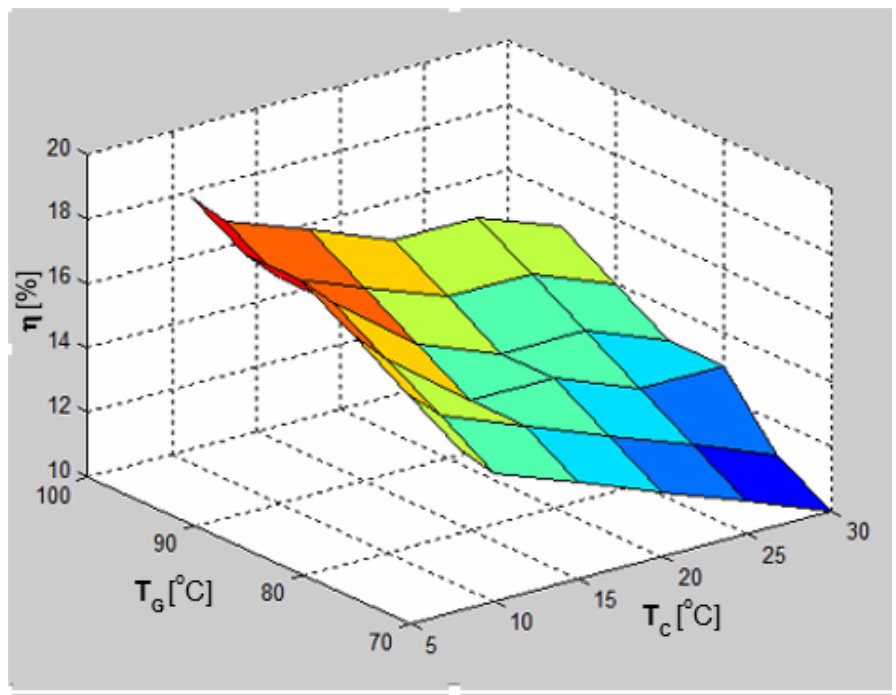

Figure 2. Thermal efficiency varying with evaporator and condenser temperature for R-123.

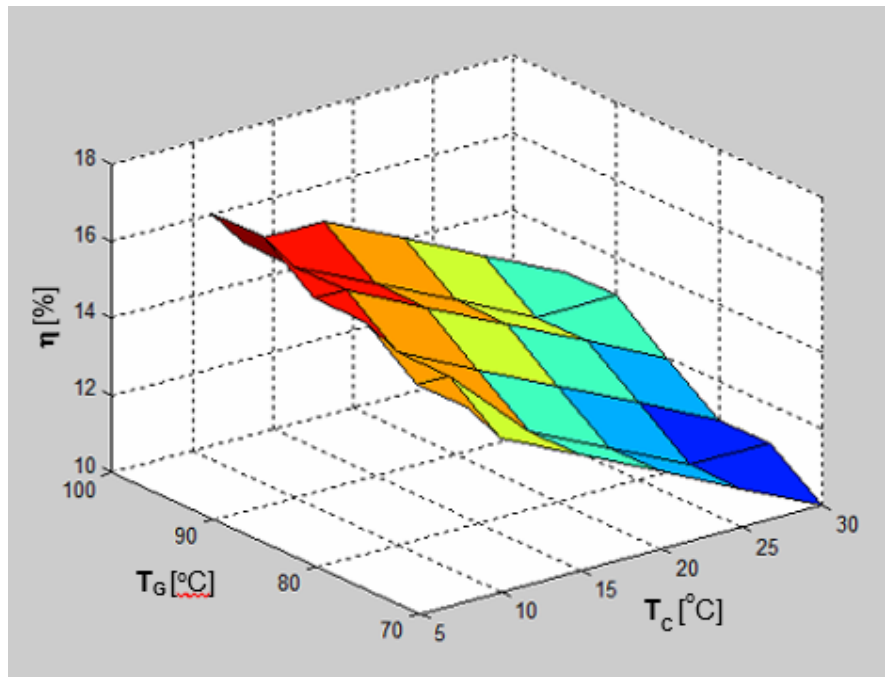

Figure 3. Thermal efficiency varying with evaporator and condenser temperature for $\mathbf{R}-134 a$.

\section{GEP Model Development}

Gene expression programming (GEP) was invented by Ferreira in 1999 [12]. GEP is the natural development of genetic algorithms (GAs) and genetic programming (GP). There are two main players in GEP. These are the chromosomes and the expression trees. The flowchart of a GEP algorithm is shown in Fig. 4. More detailed information about GEP can be obtained in the References [15-18].

Optimization and performance analysis of ORC systems in literature was carried out. In this work, the GEP method was used to estimate the thermal efficiency of the regenerative organic Rankine cycle running with R-123 and R-134a working fluids. The thermal efficiency of the regenerative Organic Rankine Cycle is mainly influenced by the steam generator, condenser, subcooling, and superheating temperature. Hence, generator temperature (TG), condenser temperature (TC), subcooling temperature (TSC) and superheating temperature (TSH) are for input parameters and the thermal efficiency predicted $(\eta)$ for output parameter. The input-output values were collected from Solkane Software. The Solkane Software is a powerful calculation program for refrigerants properties, heating, cooling, and ORC cycles [19]. Various GEP parameters were used to achieve excellent topology. The optimal GEP algorithm parameters for the prediction of the thermal efficiency for both working fluids are presented in Table 2. GeneXproTools program for the performance analysis of the RORC was used in this study [20]. 


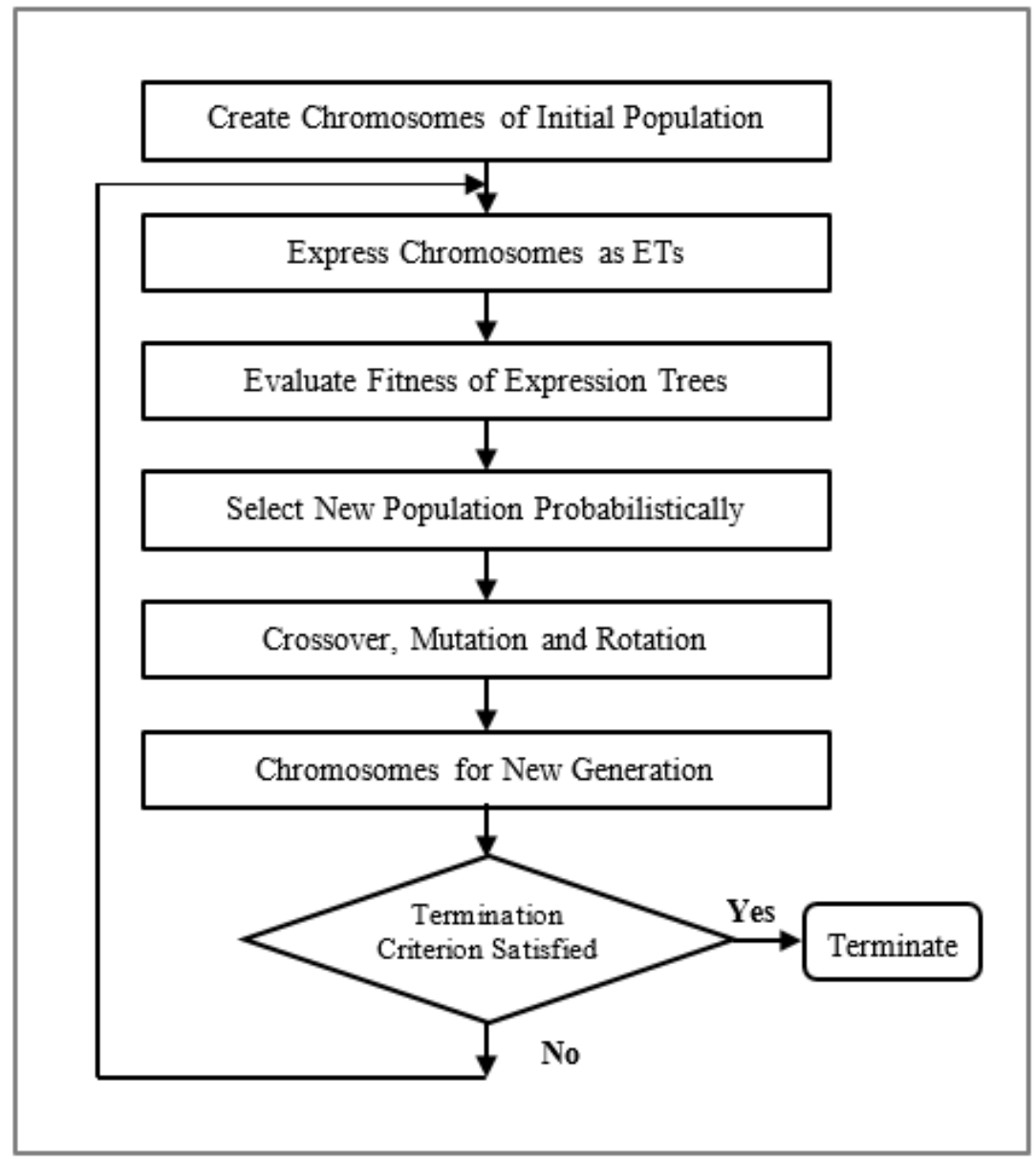

Figure 4. The GEP Algorithm.

Table 2. The GEP model parameters

\begin{tabular}{cccc}
\hline GEP model parameters & R134a & Refrigerant & R123 \\
\hline Generation number & 975152 & 6144 & 50 \\
Chromosome number & 50 & 3 & 8 \\
Gene number & 3 & Addition \\
Head length & 8 & 0.044 \\
Link feature & Addition & 0.1 \\
Ratio of mutation & 0.044 & 0.3 \\
Ratio of inversion & 0.1 & 0.3 & 0.3 \\
Ratio of one point combination & 0.3 & 0.1 \\
Ratio of two point combination & 0.1 & 0.1 \\
Ratio of gen combination & 0.1 & , power, $10^{\chi}$, ln, sin, cos, \\
Gen transposition ratio & tan, $1 / \mathrm{x}$
\end{tabular}


To evaluate the performance of the developed GEP model, root mean square error (RMSE), mean absolute percentage error (MAPE), and R-square $\left(\mathrm{R}^{2}\right)$ are used. Equations (6-8) represent the RMSE, MAPE, and $\mathrm{R}^{2}$, respectively.

$$
\begin{aligned}
& R M S E=\sqrt{\frac{\sum_{i=1}^{n}\left(a_{i}-p_{i}\right)^{2}}{n}} \sqrt{ } \\
& M A P E=\frac{1}{n}\left[\frac{\sum_{i=1}^{n}\left|a_{i}-p_{i}\right|}{\sum_{i=1}^{n} a_{i}} \times 100\right] \\
& R^{2}=\frac{\left(n \sum a_{i} p_{i}-\sum a_{i} \sum p_{i}\right)^{2}}{\left(n \sum a_{i}^{2}-\left(\sum a_{i}\right)^{2}\left(n \sum p_{i}{ }^{2}-\left(\sum p_{i}\right)^{2}\right)\right.}
\end{aligned}
$$

where $\mathrm{a}=$ actual value, $\mathrm{p}=$ predicted value and $\mathrm{n}=$ data number .

\section{Results and Discussion}

In this paper, to estimate the thermal efficiency of the regenerative Organic Rankine Cycle, the GEP model is used. R-123 and R-134a as the working fluid for the present study are considered. The mathematical formulations obtained from the GEP model for R-123 and R-134a are given in Eqs. 9-10, respectively.

$$
\begin{aligned}
& \eta_{R 123}=\frac{1}{T_{c} \sqrt{\ln \left(e^{\left.T_{c} \cdot 2 T_{S H}\right)}\right.}}+10\left(\left(T_{S H}-\sin \left(\ln \sqrt{T_{G}}\right)\right)-T_{S H}\right)+\frac{1}{\left(T_{C}-T_{S C}-T_{G}\right)+\left(T_{S H}+\frac{T_{G}}{T_{S H}}\right)} \\
& \eta_{R 134 a}=\frac{\ln \left(\ln \frac{\sqrt{T_{C}}}{2.3026}\right)}{5.3020 \cdot T_{C} \cdot T_{S H} \cdot \ln \left(T_{C}\right)}+\frac{\cos \left(\sqrt{\left(T_{G}-T_{C}\right)}\right)}{\frac{\ln \left(T_{C}^{T} S C\right.}{2.3026}-\left(T_{C}+T_{G}\right)}+\tan \left(0.1924-\tan \frac{\sqrt{T_{C}}}{T_{G}}\right)
\end{aligned}
$$

In Figs. 5-6, the predicted results from the GEP model are compared to the actual results for R-123 and R-134a, respectively. As seen in Figs. 5-6, the correlation coefficient obtained for R-123 and R-134a are 0.9532 and 0.9631, respectively. The obtained results show that the GEP model exhibits a successful performance for predicting the thermal efficiency of RORC.

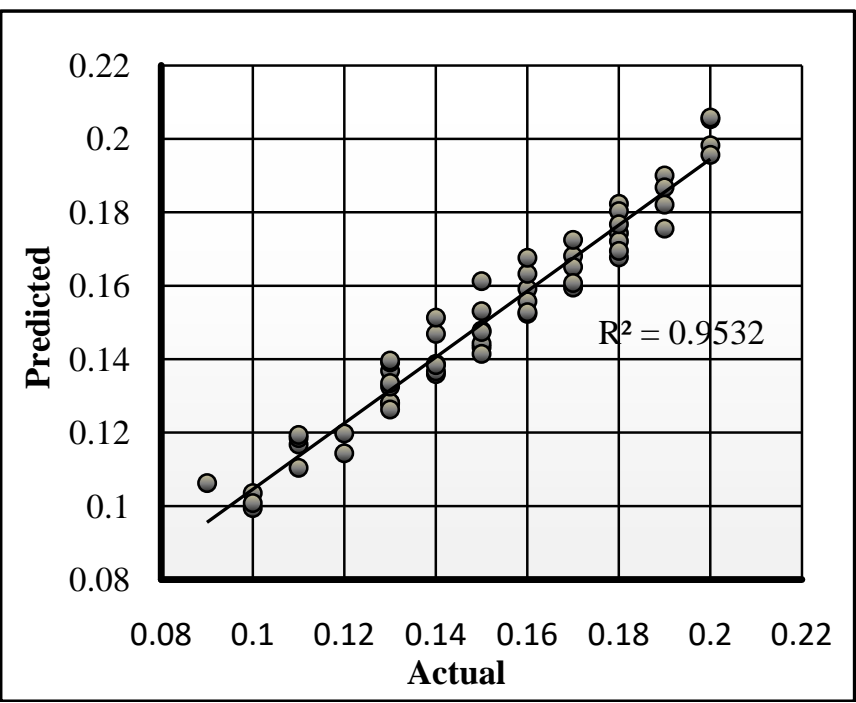

Figure 5. Correlation between actual thermal efficiency and estimated R-123. 


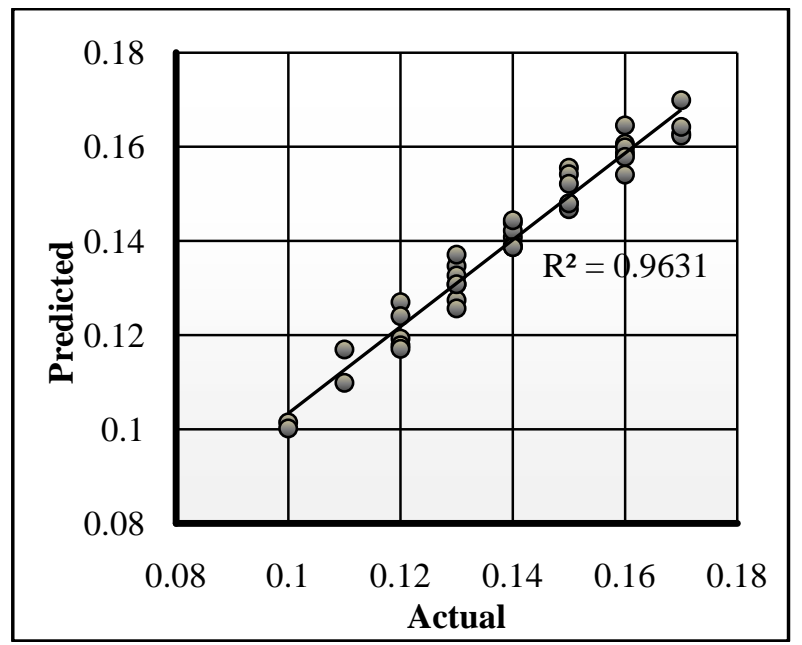

Figure 6. Correlation between actual thermal efficiency and estimated R-134a.

The performance of the GEP model is presented in Table 3. The thermal efficiency values obtained from the models provide perfect agreement with actual results. The minimum value of R2 and the maximum value of MAPE and RMSE are 0.9532, 0.01377, and 0.00004228, respectively, all for the results.

Table 3. The results of statistical calculations

\begin{tabular}{ccc}
\hline Statistical parameters & \multicolumn{2}{c}{ Refrigerant } \\
& R134a & R123 \\
\hline MAPE & 0.01226 & 0.01377 \\
RMSE & 0.00002413 & 0.00004228 \\
$\mathrm{R}^{2}$ & 0.9613 & 0.9532 \\
\hline
\end{tabular}

Tables 4 and 5 present a random comparison of the actual thermal efficiency with the results of the GEP method of the RORC for R123 and R-134a respectively. It can be seen that in most cases, the error is within an acceptable range. The maximum percentage difference is $7.72 \%$.

Figure 7 and Figure 8 present a random comparison of the actual thermal efficiency values with the results of the GEP method of the RORC in the different condenser and steam generator temperatures for R123 and R-134a respectively. As can be seen in Figure 7 and Figure 8, the actual results agree with the results obtained from the GEP model. In addition, Figure 7 and Figure 8 show the variation of the thermal efficiency $(\eta)$ of the regenerative Organic Rankine Cycle with the condenser and steam generator. As can be seen from Figure 7 and Figure 8, the thermal efficiency of the system increases when the steam generator temperature increases. The thermal efficiency of the system decreases with increasing condenser temperature.

Table 4. A random comparison of actual and GEP estimated thermal efficiency of the RORC for R123

R123

\begin{tabular}{cccccccc}
$\mathbf{T}_{\mathbf{G}}\left({ }^{\circ} \mathrm{C}\right)$ & $\mathbf{T}_{\mathbf{C}}\left({ }^{\circ} \mathrm{C}\right)$ & $\mathbf{T}_{\mathbf{S H}}\left({ }^{\circ} \mathrm{C}\right)$ & $\mathbf{T}_{\mathbf{S C}}\left({ }^{\circ} \mathrm{C}\right)$ & Actual & GEP Model & Error & Percentage difference (\%) \\
\hline 40 & 8 & 5 & 5 & 0.10 & 0.1035 & 0.0349 & 3.49 \\
55 & 15 & 10 & 10 & 0.11 & 0.1104 & 0.0004 & 0.36 \\
60 & 9 & 10 & 10 & 0.13 & 0.1391 & 0.0091 & 6.99 \\
65 & 9 & 10 & 10 & 0.14 & 0.1469 & 0.0069 & 4.93 \\
\hline
\end{tabular}




\begin{tabular}{|c|c|c|c|c|c|c|c|}
\hline 70 & 30 & 15 & 15 & 0.11 & 0.1185 & 0.0085 & 7.72 \\
\hline 75 & 25 & 15 & 15 & 0.13 & 0.1325 & 0.0025 & 1.91 \\
\hline 80 & 25 & 10 & 7 & 0.14 & 0.1384 & 0.0016 & 1.16 \\
\hline 85 & 8 & 5 & 5 & 0.18 & 0.1823 & 0.0023 & 1.29 \\
\hline 90 & 10 & 8 & 9 & 0.18 & 0.1803 & 0.0003 & 0.18 \\
\hline 95 & 25 & 5 & 10 & 0.16 & 0.1632 & 0.0032 & 2.02 \\
\hline
\end{tabular}

Table 5. A random comparison of actual and GEP estimated thermal efficiency of the RORC for R-134a

\section{R134a}

\begin{tabular}{|c|c|c|c|c|c|c|c|}
\hline $\mathbf{T}_{\mathrm{G}}\left({ }^{\circ} \mathrm{C}\right)$ & $\mathbf{T}_{\mathbf{C}}\left({ }^{\circ} \mathrm{C}\right)$ & $\mathbf{T}_{\mathbf{S H}}\left({ }^{\circ} \mathrm{C}\right)$ & $\mathbf{T}_{\mathrm{SC}}\left({ }^{\circ} \mathrm{C}\right)$ & Actual & GEP Model & Error & Percentage difference (\%) \\
\hline 50 & 10 & 8 & 8 & 0.11 & 0.1098 & 0.0001 & 0.12 \\
\hline 55 & 8 & 8 & 8 & 0.12 & 0.1256 & 0.0056 & 4.72 \\
\hline 65 & 20 & 5 & 5 & 0.11 & 0.1122 & 0.0024 & 2.04 \\
\hline 70 & 15 & 10 & 10 & 0.13 & 0.1318 & 0.0018 & 1.42 \\
\hline 75 & 30 & 5 & 5 & 0.11 & 0.1103 & 0.0003 & 0.33 \\
\hline 80 & 25 & 10 & 7 & 0.13 & 0.1260 & 0.0039 & 3.06 \\
\hline 85 & 30 & 5 & 5 & 0.12 & 0.1245 & 0.0045 & 3.77 \\
\hline 90 & 10 & 8 & 9 & 0.16 & 0.1676 & 0.0076 & 4.75 \\
\hline 95 & 8 & 10 & 10 & 0.17 & 0.1738 & 0.0038 & 2.21 \\
\hline
\end{tabular}
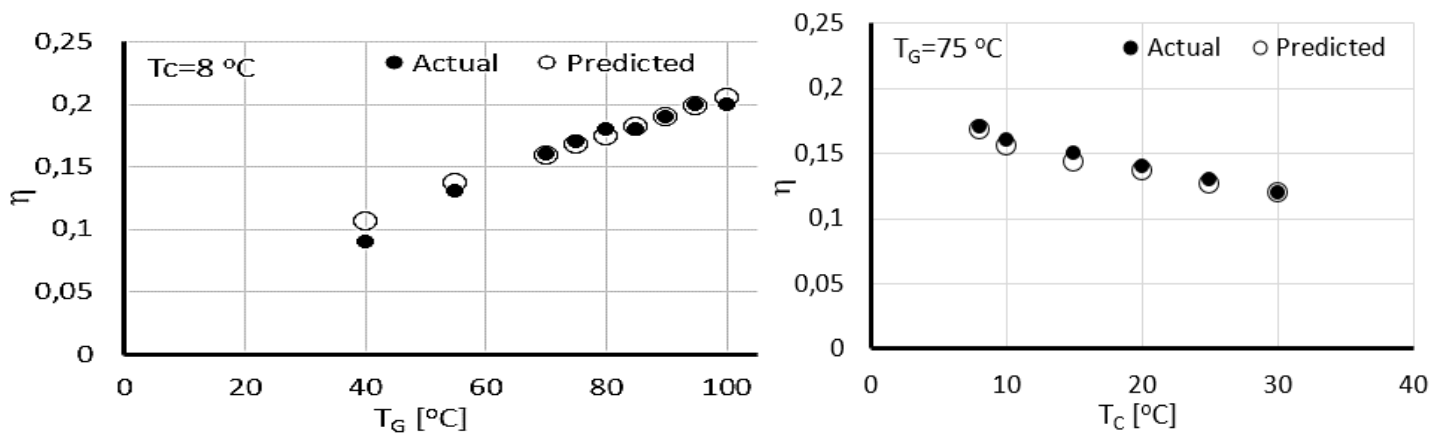

Figure 7. GEP approach compared with the actual values for R-123.
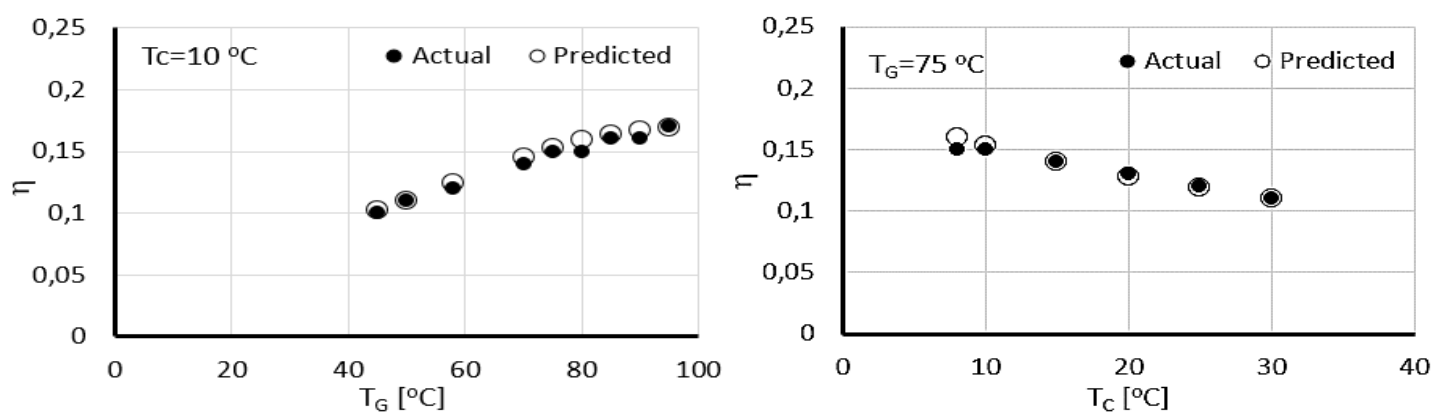

Figure 8. GEP approach compared with the actual values for $R-134 a$. 


\section{Conclusions}

In this study, the GEP method for thermal efficiency forecasting of the RORC using two different working fluids is developed. The developed model was based on actual data collected from the Solkane software. The values obtained from the GEP model demonstrate agreement with actual values. The results of $\mathrm{R}^{2}$, MAPE, and RMSE have demonstrated this situation. For R123, the finest values of RMSE, MAPE, and $\mathrm{R}^{2}$ are $0.00004228,0.01377$ and 0.9532, respectively. For R-134a, the finest values of RMSE, MAPE, and $\mathrm{R}^{2}$ are $0.00002413,0.01226$, and 0.9613 , respectively. It was observed that the GEP model can be an appropriate approach for the assessment of the thermal efficiency of the RORC. The formulas obtained from the GEP model are relatively short and simple. Also, no software is required for these formulas. These formulas will assist engineers for very correct and quick forecasting of the thermal efficiency of the regenerative organic Rankine cycle.

\section{List of symbols}

$\begin{array}{ll}\text { GEP } & \text { gene expression programming } \\ \mathrm{h} & \text { specific enthalpy, } \mathrm{kJ} / \mathrm{kg} \\ \dot{m} & \text { mass flow rate, } \mathrm{kg} / \mathrm{s} \\ \mathrm{MAPE} & \text { mean absolute percentage error } \\ \mathrm{RORC} & \text { regenerative Organic Rankine Cycle } \\ \mathrm{RMSE} & \text { root mean square error } \\ \mathrm{R}^{2} & \text { coefficient of multiple determination } \\ \dot{Q} & \text { heat transfer rate, } \mathrm{kW} \\ \mathrm{T} & \text { temperature, oC } \\ \dot{W} & \text { power, } \mathrm{kW} \\ \eta & \text { thermal efficiency }\end{array}$

\section{Subscripts}

$\begin{array}{ll}\text { p } & \text { Pump } \\ \text { C } & \text { condenser } \\ \text { G } & \text { steam generator } \\ \text { T } & \text { turbin } \\ \text { SC } & \text { subcooling } \\ \text { SH } & \text { superheating }\end{array}$

\section{Acknowledgments}

The authors declared that this study has received no financial support

\section{Authors’ contributions}

AŞŞ designed the concept. ED performed literature search. Data collection and theoretical calculations were carried out in collaboration with AŞŞ and ED, and wrote up the article. Both authors read and approved the final manuscript.

\section{Competing interests}

No conflict of interest was declared by the authors.

\section{References}

[1] Roy, J. P., Mishra, M. K., Misra, A. (2011). Parametric optimization and performance analysis of a regenerative Organic Rankine Cycle using low-grade waste heat for power generation. Int. J. Green Energy, 2011, 8: $173-196$. https://doi.org/10.1080/15435075.2010.550017. 
[2] Kumar, U., Karimi, M. N., Asjad, M. (2016). Parametric optimisation of the organic Rankine cycle for power generation from low-grade waste heat. Int. J. Sustain. Energy, 2016, 35: 774-792. https://doi.org/10.1080/14786451.2014.950962.

[3] Huang, R., Luo, X., Yang, Z., Chen, Y. (2017). Thermodynamic analysis and optimization of a novel zeotropic organic Rankine Cycle. Energy Procedia, 2017, 142: 1346-1352. https://doi.org/10.1016 /j.egypro.2017.12.518.

[4] Le, V. L., Feidt, M., Kheiri, A., Pelloux-Prayer, S. (2014). Performance optimization of low-temperature power generation by supercritical ORCs (organic Rankine cycles) using low GWP (global warming potential) working fluids. Energy, 2014, 67: 513-526. https://doi.org/10.1016/j.energy.2013.12.027.

[5] Li, J., Liu, Q., Ge, Z., Duan, Y., Yang, Z. (2017). Thermodynamic performance analyses and optimization of subcritical and transcritical organic Rankine cycles using R1234ze(E) for $100-200^{\circ} \mathrm{C}$ heat sources. Energy Convers. Manag., 2017, 149: 140-154. https://doi.org/10.1016/j.enconman.2017.06.060.

[6] Zhu, Y., Li, W., Sun, G., Li, H. (2018). Thermo-economic analysis based on objective functions of an organic Rankine cycle for waste heat recovery from marine diesel engine. Energy, 2018, 158: 343-356. https://doi.org/10.1016/j.energy.2018.06.047.

[7] Yuksel, Y. (2020). Thermodynamic and performance evaluation of an integrated geothermal energy based multigeneration plant. El-Cezeri, 2020, 7(2): 381-401.

[8] Akbay, O., Yılmaz, F. (2021). Flaş İkili Jeotermal Güç Üretim Santralinin Termodinamik Analizi ve Performans Karş1laştırmas1, El-Cezeri, 2021, 8(1): 445-461.

[9] Şencan, Ş. A., Kovac1, T., Dikmen, E. (2021). A GEP-Based Model Approach for Estimating Thermodynamic Properties of R513A Refrigerant. El-Cezeri, 2021, 8(1): 376-388.

[10] Leon, L. P., Gay, D. (2019). Gene expression programming for evaluation of aggregate angularity effects on permanent deformation of asphalt mixtures, Constr. Build. Mater., 2019, 211: 470-478. https://doi.org/10.1016/j.conbuildmat.2019.03.225.

[11] Mattar, M. A. (2018). Using gene expression programming in monthly reference evapotranspiration modeling: A case study in Egypt. Agric. Water Manag., 2018, 198: 28-38. https://doi.org/10.1016/j.agwat.2017.12.017.

[12] Kaboli, S. H. A., Fallahpour, A., Selvaraj, J., Rahim, N. A. (2017). Long-term electrical energy consumption formulating and forecasting via optimized gene expression programming. Energy, 2017, 126: $144-164$. https://doi.org/10.1016/j.energy.2017.03.009.

[13] Dikmen, E., Ayaz, M., Gül, D., Şahin, A. Ş. (2017). Gene expression programming approach for the estimation of moisture ratio in herbal plants drying with vacuum heat pump dryer. Heat Mass Transf., 2017, 53: $2419-2424$. https://doi.org/10.1007/s00231-017-1998-3.

[14] Şahin, A. Ş., Dikmen, E., Şentürk, S. (2019). A gene expression programming approach for thermodynamic properties of working fluids used on Organic Rankine Cycle. Neural Comput. Appl., 2019, 31: $3947-3955$. https://doi.org/10.1007/s00521-018-3349-9.

[15] Abraham, A., De Baets, B., Köppen, M., Nickolay, B. (Eds.). (2006). “Applied soft computing technologies: the challenge of complexity”, 34, Springer Science \& Business Media. (2006).

[16] Ferreira, C. (2001). Gene Expression Programming: a New Adaptive Algorithm for Solving Problems, 2001. http://arxiv.org/abs/cs/0102027 (accessed November 5, 2020).

[17] Ferreira, C. (2002). Combinatorial Optimization by Gene Expression Programming: Inversion Revisited, 2002. http://www.gene-expression-programming.com/webpapers/ferreira-ASAI02.pdf (accessed November 5, 2020).

[18] Ferreira, C. (2006). Gene Expression Programming Mathematical Modeling by an Artificial Intelligence, Springer. 2006. https://link.springer.com/book/10.1007\%2F3-540-32849-1 (accessed November 5, 2020).

[19] Solvay, Solkane Refrigerant Software. (2012). www.solvaychemicals.com/EN /products/Fluor/Software.aspx.

[20] GeneXproTools, APS v2 (Limited version), Automatic Problem Solver Software. http://www.gepsoft.com. 